\title{
IDENTIFIKASI PENGGUNAAN OBAT PADA PASIEN HIPERTENSI USIA LANJUT DENGAN BEER'S CRITERIA DI INSTALASI RAWAT INAP RUMAH SAKIT IBNU SINA MAKASSAR PERIODE TAHUN 2012
}

\author{
Sukmawati, Rachmat Kosman, Ira Damayanti \\ Fakultas Farmasi Universitas Muslim Indonesia \\ Email : sukmawati.sukmawati@umi.ac.id.
}

\begin{abstract}
Identification in the use medicine in geriatric patient of hypertension with Beer's Criteria In inpatient installation of Ibnu Sina Makassar hospital period 2012. In this study aims to observe and report on the use of drugs included in the Beers criteria on the use medicine in geriatrics patients of hypertension in the inpatient of Ibnu Sina Makassar Hospital. This is an observational study with the following descriptive design through the entire medical record in geriatrics patients who suffer from hypertension of Ibnu Sina Hospital in Makassar. The results showed that the types of drugs included in the Beers criteriaare nifedipine (3.44\%), alprazolam (44.82\%), lorazepam (13.79\%), diazepam (13.79), estazolam (6.89\%), metokloperamide (10.34\%), and mefenamic acid (3.44\%).
\end{abstract}

Keywords :Beers criteria, geriatrics,hypertension.

\section{PENDAHULUAN}

Populasi orang berusia lanjut di dunia mengalami pertumbuhan yang cepat saat ini. Hingga tahun 2020, populasi dunia diperkirakan mencapai lebih dari 1 milyar orang berumur 60 tahun atau lebih ${ }^{1}$.

Pada usia lanjut terjadi proses penuaan yang bisa mengakibatkan terjadinya perubahan pada berbagai organ di dalam tubuh seperti sistem gastrointestinal, sistem genitourinaria, sistem endokrin, sistem immunologis, sistem saraf pusat, dan sebagainya. Hal tersebut itulah yang menyebabkan timbulnya penyakit. Sehingga diperlukan obat-obatan untuk proses penyembuhan $^{2,3}$.

Salah satu penyakit yang biasa diderita pasien usia lanjut adalah hipertensi. Patogenesis dan penatalaksanaan penyakit ini pada usia lanjut tidak seluruhnya sama dengan pada usia muda ${ }^{4}$.Terapi dengan obat-obatan bertujuan meningkatkan kualitas atau mempertahankan hidup pasien, namun ada hal - hal yang tidak dapat dihindari yaitu kemungkinan terjadinya hasil pengobatan yang tidak 
Identifikasi Penggunaan Obat Pada Pasien Hipertensi Usia Lanjut Dengan Beer's Criteria DI Instalasi Rawat Inap Rumah Sakit Ibnu Sina Makassar Periode Tahun 2012

diharapkan ${ }^{5}$. Salah satu daftar obat yang memiliki efek samping pada pasien usia lanjut adalah Beers criteria, yang telah digunakan di beberapa negara sebagai referensi dokter dan apoteker untuk meningkatkan kualitas pengobatan pada pasien usia lanjut. Selama beberapa tahun, gerontologis Beers M.H, telah berperan besar dalam penyusunan kriteria obat yang secara ekspilsit dapat mengidentifikasi PIP (Potentially Inappropriate Prescription) 6,7 .

Berdasarkan hal tersebut, maka dilakukan penelitian terkait permasalahan penggunaan obat pada pasien usia lanjut di rumah sakit Ibnu Sina Makassar dengan parameter Beers criteria untuk meminimalkan terjadinya efek yang tidak dikehendaki.

\section{METODE PENELITIAN}

\section{Tempat dan Waktu Penelitian}

Penelitian ini dilakukan di rumah sakit Ibnu Sina Makassar pada November 2012 sampai Maret 2013.

\section{Populasi dan Sampel}

\section{Populasi}

Populasi penelitian adalah data semua pasien dengan diagnosis hipertensi yang menjalani rawat inap di rumah sakit Ibnu Sina Makassar periode Januari - Desember 2012.

\section{Sampel}

Sampel penelitian adalah data rekam medis pasien usia lanjut (60 tahun ke atas) yang menderita hipertensi yang menjalani rawat inap di rumah sakit Ibnu Sina Makassar periode Januari - Desember 2012.

\section{Metode Pengumpulan Data}

Proses pengumpulan data dimulai dari observasi mendata jumlah rekam medis pasien usia lanjut yang menderita hipertensi. Selanjutnya dilakukan pengambilan data, meliputi :

1. Profil pasien meliputi nama pasien, umur, dan jenis kelamin

2. Profil pengobatan meliputi jenis obat, dosis, dan frekuensi pemberian obat

\section{Analisis Data}

Evaluasi ketepatan dari pengobatan dapat dilakukan secara teoritis berdasarkan studi literatur.

Analisis data menggunakan metode dekskriptif untuk menentukan adanya penggunaan obat yang termasuk dalam daftar Beers criteria.Penelitian ini menggunakan metode observasional dari data - data kartu rekam medis pasien usia lanjut (60 tahun ke atas) yang menjalani pengobatan penyakit hipertensi di instalasi rawat inap rumah sakit lbnu Sina Makassar periode Januari Desember 2012. 
Identifikasi Penggunaan Obat Pada Pasien Hipertensi Usia Lanjut Dengan Beer's Criteria DI Instalasi Rawat Inap Rumah Sakit Ibnu Sina Makassar Periode Tahun 2012

\section{HASIL PENELITIAN}

\section{Karakteristik Pasien}

Tabel 1. Persentase jenis kelamin pasien usia lanjut yang menderita hipertensi di instalasi rawat inap rumah sakitlbnu Sina Makassar periode Januari Desember 2012.

\begin{tabular}{cccc}
\hline No. & Jenis kelamin & Jumlah (pasien ) & Persentase (\%) \\
\hline 1. & Perempuan & 32 & 64 \\
2. & Laki- laki & 18 & 36 \\
\hline & Total & $\mathbf{5 0}$ & $\mathbf{1 0 0}$ \\
\hline
\end{tabular}

\section{Pola Pengobatan Berdasarkan Golongan Dan Jenis}

Tabel 2. Persentase penggunaan obat yang termasuk dalam daftar Beers criteria pada pasien usia lanjut yang menderita hipertensi di instalasi rawat inap rumah sakitlbnu Sina Makassar periode Januari - Desember 2012

\begin{tabular}{|c|c|c|c|c|c|c|}
\hline \multirow{2}{*}{ No } & \multirow{2}{*}{ Nama obat (Paten) } & \multicolumn{3}{|c|}{ Kriteria penggunaan obat } & \multirow{2}{*}{$\begin{array}{l}\text { Jumlah } \\
\text { (kasus) }\end{array}$} & \multirow{2}{*}{$\begin{array}{c}\text { Persentase } \\
\text { (\%) }\end{array}$} \\
\hline & & Potensi & Frekuensi & Dosis & & \\
\hline 1. & Nifedipin (Adalat Oros) & $20 \mathrm{mg}$ & $1 \times 1$ & $20 \mathrm{mg}$ & 1 & 3,44 \\
\hline 2. & $\begin{array}{l}\text { Alprazolam (Xanax, } \\
\text { Apazol) }\end{array}$ & $0,5 \mathrm{mg}$ & $1 \times 1$ & $0,5 \mathrm{mg}$ & 13 & 44,82 \\
\hline 3. & Lorazepam (Renaquil) & $1 \mathrm{mg}$ & $1 \times 1$ & $1 \mathrm{mg}$ & 4 & 13,79 \\
\hline 4. & Diazepam (Valisanbe) & $2 \mathrm{mg}$ & $1 \times 1$ & $2 \mathrm{mg}$ & 4 & 13,79 \\
\hline 5. & Estazolam (Esilgan) & $1 \mathrm{mg}$ & $1 \times 1$ & $1 \mathrm{mg}$ & 2 & 6,89 \\
\hline 6. & $\begin{array}{l}\text { Metokloperamid } \\
\text { (Kalmeco) }\end{array}$ & $500 \mathrm{mcg}$ & $3 \times 1$ & $500 \mathrm{mcg}$ & 3 & 10,34 \\
\hline 7. & $\begin{array}{l}\text { Asam mefenamat } \\
\text { (Mefinal) }\end{array}$ & $500 \mathrm{mg}$ & $3 \times 1$ & $500 \mathrm{mg}$ & 1 & 3,44 \\
\hline & & Total & & & 29 & 100 \\
\hline
\end{tabular}

\section{PEMBAHASAN}

Penelitian ini menggunakan metode observasional dari data - data kartu rekam medis pasien usia lanjut (60 tahun ke atas) yang menjalani pengobatan penyakit hipertensi di instalasi rawat inap rumah sakit lbnu Sina Makassar periode tahun $2012^{8}$.

Penelitian ini dilakukan untuk mengamati dan melaporkan penggunaan obat yang termasuk dalam daftar Beers criteria pada pengobatan penyakit hipertensi pasien usia lanjut (60 tahun ke atas) di instalasi rawat inap rumah sakit Ibnu Sina Makassar periode tahun 2012.

Berdasarkan pengamatan yang dilakukan dari data pasien usia lanjut (60 tahun ke atas) yang menjalani pengobatan penyakit hipertensi 
Identifikasi Penggunaan Obat Pada Pasien Hipertensi Usia Lanjut Dengan Beer's Criteria DI Instalasi Rawat Inap Rumah Sakit Ibnu Sina Makassar Periode Tahun 2012

sebanyak 50 pasien hipertensi, dimana pasien perempuan sebanyak $64 \%$ yang menderita hipertensi sedangkan pasien laki - laki hanya 36 $\%$. Hal ini terjadi karena perempuan usia lanjut (60 tahun ke atas) telah mengalami masa menopause, dimana pada masa ini terjadi peningkatan produksi hormone estrogen yang merupakan salah satu faktor resiko timbulnya penyakit hipertensi ${ }^{6,9}$.

Identifikasi penggunaan obat berdasarkan daftar Beers criteria pada pasien usia lanjut yang menjalani pengobatan di instalasi rawat inap rumah sakit Ibnu Sina Makassar periode tahun 2012, ditemukan sebanyak 7 macam obat yang termasuk dalam Beers criteria yaitu nifedipin, alprazolam, lorazepam, diazepam,estazolam, metokloperamid, dan asam mefenamat ${ }^{10,11}$.

Nifedipin adalah obat antihipertensi golongan antagonis kalsium atau Calcium Chanel Blocker $(\mathrm{CCB})^{12,13}$. Berdasarkan American Geriatrics Society obat ini dapat menurunkan tekanan darah dengan cepat (hipotensi) dan dapat menyebabkan gangguan jantung lain dan tidak disetujui untuk pengobatan hipertensi,sehingga direkomendasikan untuk menghindari penggunaan nifedipin pada pasien usia lanjut (60 tahun ke atas), tetapi penggunaan nifedipin dapat diganti dengan obat amlodipine yang onset kerjanya tidak menyebabkan hipotensi akut ${ }^{10,14}$.

Alprazolam, lorazepam, diazepam, dan estazolam merupakan golongan obat benzodiazepine yang penggunaannya tidak sesuai digunakan pada pasien usia lanjut, karena pada usia lanjut khususnya yang sensitif dengan obat ini dapat meningkatkan risiko kemunduran mental, delirium (tidak bisa berpikir jernih), jatuh, dan patah tulang. Kemunduran mental dan delirium (tidak bisa berpikir jenih) terjadi apabila penggunaan obat dihentikan setelah beberapa lama terapi, terapi jangka panjang, dan penggunaan dosis tinggi.Jatuh dan patah tulang, dapat dipicu karena efek samping obatyaitu pusing, lemah, mengantuk yang dapat mengurangi konsentrasi, dan keseimbangan pasien ${ }^{15,16}$. Selain itu juga dapat disebabkan karena kurangnya kepadatan tulang pada pasien usia lanjut ${ }^{12}$. American Geriatrics Society merekomendasikan untuk menghindari penggunaan benzodiasepin (semua jenis) ketika perawatan insomnia, agitasi atau delirium (kebingungan serius yang lama), hal tersebut dapat dihindari dengan memperhatikan dosis dan 
Identifikasi Penggunaan Obat Pada Pasien Hipertensi Usia Lanjut Dengan Beer's Criteria DI Instalasi Rawat Inap Rumah Sakit Ibnu Sina Makassar Periode Tahun 2012

lamanya pemakaian sehingga tidak timbul efek yang tidak diinginkan ${ }^{10}$.

Metokloperamid adalah golongan antiemetik yang digunakan untuk mencegah atau mengurangi mual dan muntah ${ }^{12}$. Penggunaan metokloperamid pada pasien usia lanjut dapat menyebabkan kegoyahan, mengantuk, lemah, dan gerakan tubuh yang abnormal tak terkendali ${ }^{11}$. Hal tersebut terkait dengan mekanisme kerja metokloperamid yang dapat mempercepat pengosongan isi perut sehingga menyebabkan kondisi tersebut. Gerakan tubuh yang abnormal tak terkendali terjadi karena penggunaan metokloperamid dalam jangka panjang (lebih dari 12 minggu) 12,16, sehingga direkomendasikan oleh American Geriatrics Society untuk menghindari penggunaannya, kecuali untuk gastroparesis.Untuk mencegah atau mengurangi mual dan muntah biasa diberikan ondasentron, domperidon, dan dimenhidrat, obat tersebut sering digunakan dalam pengobatan hipertensi ${ }^{10}$.

Asam Mefenamat merupakan kelompok antiinflamasi non steroid

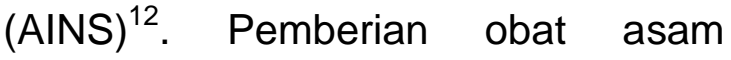
mefenamat pada pasien usia lanjut tidak dianjurkan karena obat ini meningkatkan aktivitas perut dan pendarahan usus pada umur 65 atau lebih dan umur 75 tahun $^{6,10}$. NSAID menyebabkan kerusakan mukosa saluran cerna dan pendarahan usus melalui dua mekanisme iritasi topikal, dan inhibisi sistemik sintesis $P^{12,16}$. American Geriatrics Society merekomendasikan untuk tidak menggunakan obat ini secara teratur kecuali tidak ada alternatif efektif lainnya dan diresepkan untuk jangka panjang dengan penghambat pompa proton/ misoprostol. Untuk menghindari penggunaan asam mefenamat sebagai analgetik pada pasien usia lanjut dapat diberikan obat alternative lain seperti parasetamol dan metampiron sehingga efek yang tidak diinginkan dapat dicegah ${ }^{10,11}$.

\section{KESIMPULAN}

1. Penggunaan obat pada pasien hipertensi usia lanjut di instalasi rawat inap rumah sakit Ibnu Sina Makassar periode tahun 2012 terdapat obat- obat yang termasuk dalam daftar Beers criteria.

2. Jenis - jenis obat yang termasuk dalam Beers criteria yaitu Nifedipin (3,44 \%), Alprazolam (44,82 \%), Lorazepam (13,79\%), Diazepam $(13,79)$, Estazolam (6,89 \%), Metokloperamide (10,34\%), dan Asam mefenamat $(3,44 \%)$. 


\section{DAFTAR PUSTAKA}

1. Darmodjo RB. Trough Healthy and Active Ageing to Successful Ageing Naskah Lengkap Konggres Nasional III dan Temu IImiah Nasional II Perhimpunan Gerontologi Medik Indonesia, 2004.

2. Shoor RI, Angela BH, Nathan R. Drug for the geriatric patient. Elsevier inc: Philadephia, 2007.

3. Azizah ML. (). Keperawatan Lanjut Usia. Graha ilmu : Yogyakarta, 2011.

4. Pratiwi I. Rasionalitas penggunaan Obat Antihipertensi Dengan Parameter Tepat Dosis Pada Penderita Hipertensi Di Instalasi Rawat Inap RSUD Labuang Baji Makassar 2011.(Skripsi). Universita Muslim Indonesia : Makassar, 2012.

5. Simarmata M. ().Masalah Terkait Obat (Drug Related Problem). Intervensi apoteker. FMIPA Universitas Indonesia : Jakarta, 2010.

6. Tobat RS. Identifikasi Pip (Potentially Inappropriate Prescription) dan ADR (Adverse Drug Reaction) Pada Pasien Geriatri Di Bagian/Smf Rawat Inap Penyakit Dalam Rsup. Dr.M.Djamil Padang (Tesis). Universitas Andalas Padang, 2011.

7. Januar GM, Ikawati Z, Raharjo B. Pengaruh pemberian Informasi Obat Berdasarkan Beers Criteria Terhadap Pola Pemberian Obat Pada Pasien Usia Lanjut Rawat Inap Penyakit Dalam Di RSUD Prof. Dr. Margono Soekarjo Purwokerto Periode Mei - Agustus 2010. Universitas Gajah Mada : Yogyakarta, 2010.
8. Rahmawati $F$, Ellykusuma $Y N$, Pramantara PD, Sulaiman SAS. ().Problem pemilihan obat pada pasien Rawat inap geriatri di rsup dr. Sardjito Yogyakarta. Jurnal Farmasi Indonesia 2008.

9. Fitriani R. Identifikasi Drug Related Problems (DRPs) Kategori Kontraindikasi dan Ketidaktepatan Dosis Obat Pada Pasie Hipertensi Geriatri Di Instalasi Rawat Inap RSUD Dr. Moerwadi Surakarta Tahun 2007 (Skripsi). Fakultas Farmasi. Universitas Muhammadiyah Surakarta : Surakarta, 2009.

10. AGS. Identifying Medications that Older Adults Should Avoid or Use With Caution: the 2012 American Geriatrics SocietyUpdated Beers Criteria. Maret 2012. Diakses 5 Desember

2012.www.americangeriatrics.org.

11. Direktorat Jenderal Bina Kefarmasian dan Alat Kesehatan Departemen Kesehatan Republic Indonesia. Pedoman Pelayanan farmasi (Tata Laksana Terapi Obat) Untuk Pasien Geriatric: Jakarta, 2006.

12. Olson J. Belajar Mudah Farmakologi. EGC Penerbit Buku Kedokteran : Jakarta, 2008.

13. Peter K. Bagaimana menggunakan obat - obat kardiovaskular secara rasional. Balai penerbit FKUI : Jakarta, 2010.

14. Direktorat Jenderal Bina Kefarmasian Dan Alat Kesehatan Departemen Kesehatan Republic Indonesia. Pharmaceutical CareUntuk Penyakit Hipertensi: Jakarta, 2006. 
Identifikasi Penggunaan Obat Pada Pasien Hipertensi Usia Lanjut Dengan Beer's Criteria DI Instalasi Rawat Inap Rumah Sakit Ibnu Sina Makassar Periode Tahun 2012

15. Ikawati Z. Farmakoterapi Penyakit Sistem Saraf Pusat. Bursa Ilmu: Yogyakarta, 2011.

16. Dipiro JT, Robert LT, Gary CY, Barbara GW, Michael P.
Pharmacotherapy pathophysiology

A Seventh Edition, Mc Graw Hill Companies, 2008. approach, , 